\title{
REPORT OF THE TREASURER FOR THE YEAR 1921
}

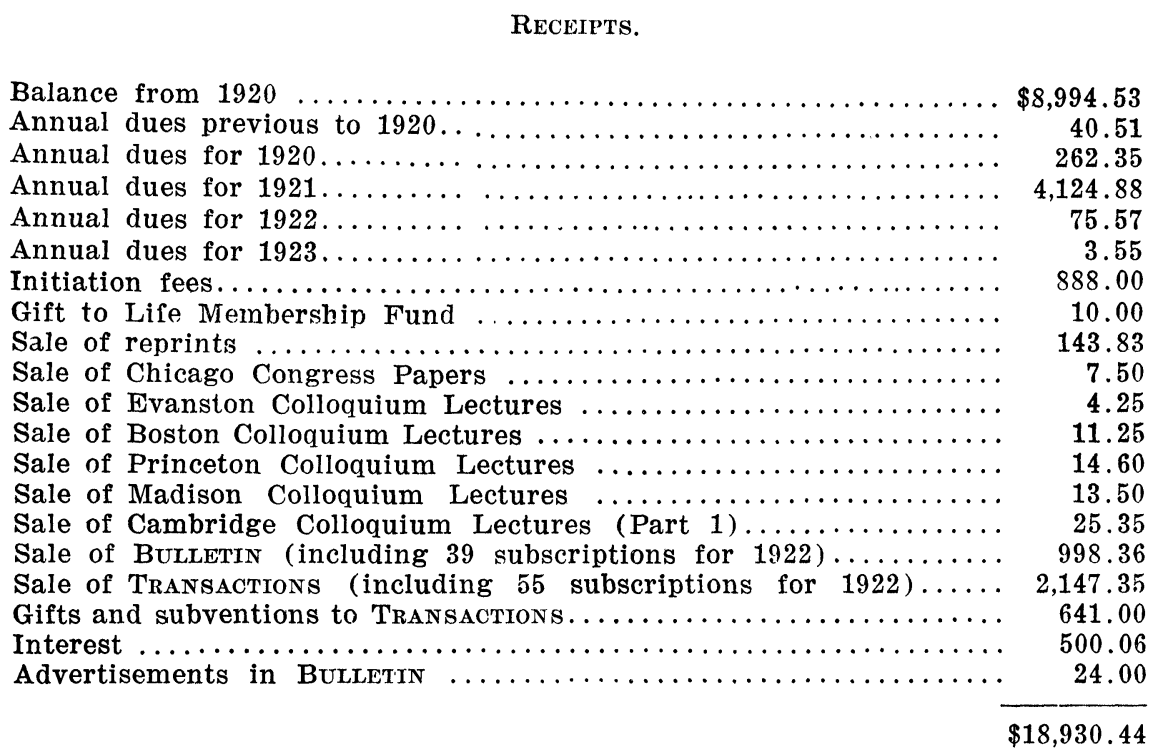

Disbursements.

Secretary's Office $\ldots \ldots \ldots \ldots \ldots \ldots \ldots \ldots \ldots \ldots \ldots \ldots \ldots \ldots \ldots \ldots$

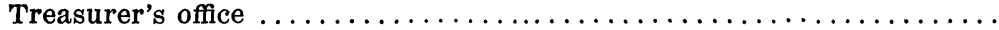

763.99

105.86

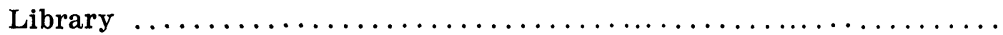

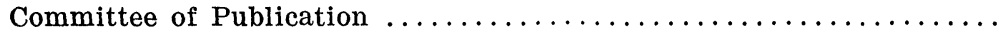

141.78

Editorial Committee of Transactions $\ldots \ldots \ldots \ldots \ldots \ldots \ldots \ldots \ldots \ldots, 125.78$

BULletin (seven numbers) $\ldots \ldots \ldots \ldots \ldots \ldots \ldots \ldots \ldots \ldots \ldots \ldots, 2,311.73$

Transactions, (three numbers) $\ldots \ldots \ldots \ldots \ldots \ldots \ldots \ldots \ldots \ldots \ldots, 2,501.63$

Chicago Section $\ldots \ldots \ldots \ldots \ldots \ldots \ldots \ldots \ldots \ldots \ldots \ldots \ldots \ldots \ldots \ldots \ldots, 157.77$

San Francisco Section $\ldots \ldots \ldots \ldots \ldots \ldots \ldots \ldots \ldots \ldots \ldots \ldots \ldots \ldots, \quad 35.50$

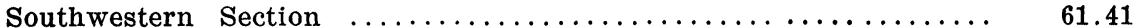

Salary of Clerk $\ldots \ldots \ldots \ldots \ldots \ldots \ldots \ldots \ldots \ldots \ldots \ldots \ldots \ldots \ldots \ldots \ldots \ldots \ldots \ldots \ldots, 1,480.00$

Committee on Bibliography $\ldots \ldots \ldots \ldots \ldots \ldots \ldots \ldots \ldots \ldots \ldots \ldots \ldots \ldots, 2.75$

Committee on Membership ............................. 200.18

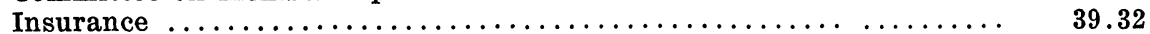

Collection and Exchange $\ldots \ldots \ldots \ldots \ldots \ldots \ldots \ldots \ldots \ldots \ldots \ldots \ldots \ldots, 22.35$

Euler Subscription $\ldots \ldots \ldots \ldots \ldots \ldots \ldots \ldots \ldots \ldots \ldots \ldots \ldots \ldots, \quad \mathbf{8 5 . 5 0}$

$\$ 8,326.22$ 
Investments (par value $\$ 8,600.00) \ldots \ldots \ldots \ldots \ldots \ldots \ldots, 261.47$

Balance in Corn Exchange Bank exclusive of special

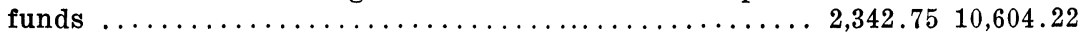

$\$ 18,930.44$

The total balance in the Corn Exchange Bank includes the following funds:

Cole Fund, principal and interest $\ldots \ldots \ldots \ldots \ldots \ldots \ldots \ldots \ldots \ldots \ldots \ldots 481.82$

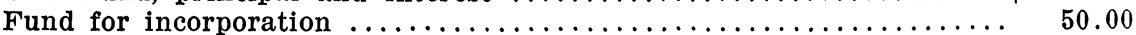

Bôcher Fund, uninvested principal and interest............. 89.50

$\$ 621.32$

Bank balance available for expenditures $\ldots \ldots \ldots \ldots \ldots \ldots \ldots \ldots \ldots 2,342.75$

Total Bank Balance .......................\$2,964.07

It should be noticed that this statement makes no provision for the cost of the Transactions for July and the June-July number of the Bulletin, which are usually paid for by this time. These two items amount to approximately $\$ 1,500.00$. The effective balance is therefore only $\$ 842.75$.

The Life Membership Fund now amounts to $\$ 7,528.87$.

W. BenJamin Fite,

Treasurer.

NEw YoRK, N. Y.,

December 21, 1921.

\section{REPORT OF THE AUDITING COMMITTEE}

The undersigned Auditing Committee, appointed by the American Mathematical Society, have this day examined the accounts of the Treasurer, compared them with the vouchers, bank book, and securities, and find the following to be correct:

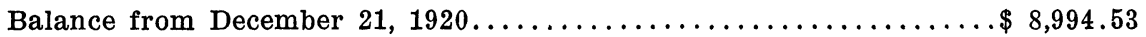

Cash receipts since December 21, $1920 \ldots \ldots \ldots \ldots \ldots \ldots \ldots \ldots \ldots \ldots .9 . \ldots 35.91$

$\$ 18,930.44$

Balance in Corn Exchange Bank, New York City, exclusive

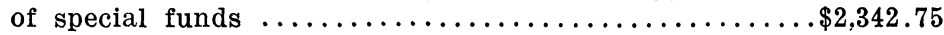

Investments (par value $\$ 8,600.00) \ldots \ldots \ldots \ldots \ldots \ldots \ldots, 261.47$

Disbursements since December $21,1920 \ldots \ldots \ldots \ldots \ldots \ldots \ldots . . \ldots, 326.22$

$\$ 18,930.44$

The following special funds are also deposited in the Corn Exchange Bank:

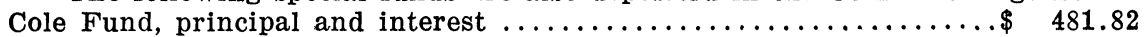

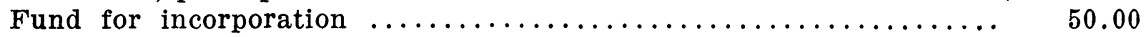
Bôcher Fund, uninvested principal and interest.............. 89.50

$\$ 621.32$

S. A. Joffe,

P. H. LiNeHAN,

New York, N. Y.,

Auditing Committee.

December 21, 1921. 